BUNDA EDU-MIDWIFERY JOURNAL (BEMJ)

p-ISSN: 26227482 dan e-ISSN: 26227487

Vol. 4 No. 2 (2021)

\title{
THE ROLE OF GINGER ADMINISTRATION TOWARD OXIDATIVE STRESS IN WOMEN'S HEALTH REPRODUCTION: A LITERATURE REVIEW
}

\author{
Riska Yasmin ${ }^{1}$, Desi Pertiwi ${ }^{2}$, Rahmawati $^{3}$ \\ 1,2 Sekolah Tinggi Ilmu Kesehatan Mutiara Mahakam \\ ${ }^{3}$ Akademi Kebidanan Bunga Husada \\ E-mail: ryasminmodak@gmail.com
}

Keywords:
Ginger; Oxidative
stress; Women;
Health
Reproduction;
Reproduction

\begin{abstract}
Objectives This study as a system review was aimed to review the role of ginger administration in reducing oxidative stress level for women in their reproduction health. This was literature review to give further information about the role of ginger in reducing oxidative stress condition and was written with the help from secondary data analysis such as databases, various journals, books, articles and key words

Result Ginger could be one of the alternative medicine to treat reproductive problems like PCOS, help the implantation process in the uterus, normalized estrogen and progesterone imbalance, reduce cortisol level which can affect women fertility, and help womento deal with premenstrual syndrome

Conclusion Ginger commonly used in herbal medicine and has antioxidant and anti-inflammatory effect on women's health reproduction due to its flavonoid, phenolic compunds and the active antioxidant such as shagaols, gingerol, zingerone to prevent ROS buildup.
\end{abstract}

\section{INTRODUCTION}

Adequate administration of micronutrient supplementation leads to improvement of nutrition in young women who intended to pregnant (1) Studies have shown that overnutrition and lifestyles promote free radicals production and affect female fertility (2) Oxidative stress is imbalance condition between free radicals and antioxidant, this condition can leads to several reproduction complication such as endometriosis, PCOS, infertility, miscarriage, preeclampsia, IUGR, premature and pre-labour rupture membrane (3) Polycystic Ovarian Syndrome (PCOS) is associated with reproductive complication and metabolic disorders which characterized by irregularr menstruation, oligo, or amenorrhea, unovulation (4) Natural medicine is used commonly over $80 \%$ of the world population. Ginger (Zingiber officinale) is one of the natural dietary component and has an antioxidant properties (5) Ginger extract has a significant natural antioxidant by scavenging superoxide radicals and lipid peroxide (6) Complementary treatment that commonly used for women reproduction problem is Ginger. It has 
been used for pain treatment such as dysmenorrhea since ginger has a role to suppress the synthesis of prostaglandin (7)

Cortisol level as an indicator for oxidative stress secreted by the adrenal cortex as physiological response and the escalation of glutathione hormone as the main antioxidant as a response as well (6,8-10) Gelam honey and Ginger combination significantly reduce triglyceride level and showed a significant decrease of MDA concentration in diabetic rats which diabetic conditions might occurs in pregnancy periode (11). The imbalance of antioxidant and prooxidant cause lipid peroxide, in previous studies the administration of ginger and rosemary oil combination reduce rats cholesterol level significantly since those materials contain gingerol, shagaols, zingerone, and paradol which has hipolipidemic effects (12) Ethanol substance in ginger can prevent oxidative stress and increase activity of enzymatic and nonenzymatic antioxidant (6) this review study provides overview of the current role of ginger and other mixture for women health reproduction

\section{METHODS}

This article was identified based on study question. The keywords are Ginger; Oxidative Stress; Women; Reproduction; Health Reproduction or the combination of the keywords and searched through Pubmed, Hindawi, Elsevier, ScienceDirect for relevant studies in exploring the role of ginger toward oxidative stress in women health reproduction.

\section{RESULT}

Following the inclusion criteria in the search was found 84 articles, and were filtered in the last 5 years. From the six selected articles most of them used in vitro or in vivo study design to determine the role of ginger toward oxidative stress for women health reproduction. Based on the 6 selected articles mainly discuss about ginger's role as an antioxidant.

Table 1. Characteristics, Instruments, and Results of Selected Studies

\begin{tabular}{|c|c|c|c|c|c|}
\hline Author & Purpose & Population & Instrument & Study Design & Result \\
\hline $\begin{array}{l}\text { Yilmaz } \\
\text { et al, } \\
2017\end{array}$ & $\begin{array}{l}\text { To investigate } \\
\text { ginger powder } \\
\text { effect of ovarian } \\
\text { foliculogenesis } \\
\text { and implantation } \\
\text { in rats }\end{array}$ & $\begin{array}{l}\text { Female } \\
\text { albino rats }\end{array}$ & $\begin{array}{l}\text { Histopatological and } \\
\text { immunihistochemical } \\
\text { examination }\end{array}$ & $\begin{array}{l}\text { In } \\
\text { laboratory } \\
\text { research }\end{array}$ & $\begin{array}{l}\text { Ginger which has } \\
\text { antioxidant } \\
\text { substance give a } \\
\text { positive effect on } \\
\text { folliculogenesis } \\
\text { in short term and } \\
\text { may enhance } \\
\text { implantation in } \\
\text { rats in long term }\end{array}$ \\
\hline $\begin{array}{l}\text { Najim, } \\
2017\end{array}$ & $\begin{array}{l}\text { To give further } \\
\text { information of } \\
\text { ginger } \\
\text { phytochemistry }\end{array}$ & & & $\begin{array}{l}\text { Systematic } \\
\text { review }\end{array}$ & $\begin{array}{l}\text { It was found that } \\
\text { ginger is useful in } \\
\text { many acute and } \\
\text { chronic } \\
\text { conditions such } \\
\text { as nausea, } \\
\text { vomiting, } \\
\text { menstrual cramp, } \\
\text { reducing gas, } \\
\text { joint pain, } \\
\text { asthma, } \\
\text { congestive } \\
\text { conditions, and as } \\
\text { an aphrodisiac }\end{array}$ \\
\hline
\end{tabular}


Table 1. (Cont.)

\begin{tabular}{|c|c|c|c|c|c|}
\hline Author & Purpose & Population & Instrument & Study Design & Result \\
\hline $\begin{array}{l}\text { Pasciu et al } \\
2019\end{array}$ & $\begin{array}{l}\text { Evaluate } \\
\text { curcuma and } \\
\text { ginger mixture as } \\
\text { natural } \\
\text { antioxidant could } \\
\text { protect cells } \\
\text { against ROS } \\
\text { induced by BPS } \\
\text { on hepatic cells }\end{array}$ & $\begin{array}{l}\text { Male Wistar } \\
\text { rats }\end{array}$ & $\begin{array}{l}\text { Folin-Ciocalteu } \\
\text { assay and } \\
\text { Molecular Probes }\end{array}$ & In vitro study & $\begin{array}{lr}\text { Curcuma and } \\
\text { ginger mixture } \\
\text { was able to } \\
\text { decrease ROS } \\
\text { production in } \\
\text { hepatic cells }\end{array}$ \\
\hline $\begin{array}{l}\text { Atashpour } \\
\text { et al, } 2017\end{array}$ & $\begin{array}{l}\text { To compare } \\
\text { effectiveness } \\
\text { ginger with } \\
\text { clomiphene } \\
\text { citrate on sexual } \\
\text { hormones }\end{array}$ & $\begin{array}{l}\text { Adult } \\
\text { Female } \\
\text { Wistar rats } \\
(7-8 \mathrm{wk})\end{array}$ & $\begin{array}{l}\text { Biochemical } \\
\text { measurement and } \\
\text { Sexual hormones } \\
\text { measurement kits }\end{array}$ & $\begin{array}{l}\text { Experimental and } \\
\text { randomized } \\
\text { study }\end{array}$ & $\begin{array}{l}\text { Ginger as herbal } \\
\text { medicine can be } \\
\text { effective and } \\
\text { good alternative } \\
\text { in improving } \\
\text { PCOS by } \\
\text { improving FSH } \\
\text { serum level }\end{array}$ \\
\hline $\begin{array}{l}\text { Permatasari } \\
\text { et al, } 2020\end{array}$ & $\begin{array}{l}\text { To investigate } \\
\text { the effect of } \\
\text { ginger honey and } \\
\text { cocktail honey on } \\
\text { decreasing } \\
\text { cortisol hormone } \\
\text { levels }\end{array}$ & $\begin{array}{l}\text { Balb/c } \\
\text { Female mice }\end{array}$ & $\begin{array}{l}\text { Cortisol ELISA } \\
\text { kit }\end{array}$ & $\begin{array}{l}\text { In vivo study pre- } \\
\text { test-post-test } \\
\text { control grou }\end{array}$ & $\begin{array}{l}\text { Ginger honey } \\
\text { combination } \\
\text { could } \\
\text { significantly } \\
\text { reduce cortisol } \\
\text { hormone levels } \\
\text { and can be used } \\
\text { as a supplement } \\
\text { to deal with } \\
\text { stress. }\end{array}$ \\
\hline $\begin{array}{l}\text { Khayat, } \\
2014\end{array}$ & $\begin{array}{l}\text { To evaluate } \\
\text { effects of ginger } \\
\text { on severity of } \\
\text { symptoms of } \\
\text { PMS }\end{array}$ & $\begin{array}{l}\text { Female } \\
\text { students }\end{array}$ & $\begin{array}{l}\text { Daily record scale } \\
\text { questionnaire }\end{array}$ & $\begin{array}{l}\text { Clinical trial, } \\
\text { double-blinded } \\
\text { work }\end{array}$ & $\begin{array}{l}\text { Ginger is } \\
\text { effective in the } \\
\text { reduction of } \\
\text { severity of mood } \\
\text { and physical and } \\
\text { behavioral } \\
\text { symptoms of } \\
\text { PMS and suggest } \\
\text { ginger as } \\
\text { treatment for } \\
\text { PMS. }\end{array}$ \\
\hline
\end{tabular}




\section{DISCUSSION}

From the six article above ginger's role as an antioxidant could significantly reduce oxidative stress condition. Ginger suppress ROS buildup and maintain free radicals in physiology condition for proper function and homeostasis, the active antioxidant such as shagaols, gingerol, zingerone present antioxidant activity which involved in generation of ROS (Reactive Oxygen Species) (13) Ginger has free radical and protective DNA damage effects since it has volatile oil (14) In male Wistar rats induced by free radical the mixture of ginger and curcuma at the 100 $\mathrm{mcg} / \mathrm{ml}$ dose was able to decrease ROS $32 \%$ and $43 \%$ in hepatic cell treated with 150 and $70 \mathrm{mcg} / \mathrm{ml}$ BPS, curcuma and ginger combination could be an efficient diet strategy to prevent pro-oxidant effect of BPS (15) In other reproductive and metabolic disorders like PCOS is characterized by increasing of $\mathrm{LH}$, testosterone, and prolactin hormones, the administration of $100 \mathrm{mg}, 175 \mathrm{mg}$, and $350 \mathrm{mg} / \mathrm{kg} /$ day for 88 days in adult female rats could decrease LH and estrogen level and increased FSH and progesterone level, Ginger extract has better effects to treat PCOS, Flavonoid and phenolic compounds in ginger could exhibit antioxidant activity and make balance between estrogen and progesterone hormone (16) in the recent studies, ginger honey mixture with 28 $\mathrm{mg} / \mathrm{kg} /$ day for 14 days could decrease cortisol level as the indicator of oxidative stress (17). The existence of stressful that leads to oxidative stress conditions can suppress the circulation of gonadotropins and steroid hormones, which will result in the disruption of the menstrual cycle. The decrease in GnRH is due to the increased secretion of CRH (18) Beside its antioxidant effect, ginger has antiinflammatory effect as well for women health reproduction, Ginger inhibit the metabolism of cyclooxygenase and lipoxygenase to prevent prostaglandin production, this can help women to deal with premenstrual syndrome such as dysmenorrhea (19)

\section{CONCLUSION}

Ginger is one of the natural herbal medicine that commonly used in complementary or alternative treatment. It has so many benefits for young and adult women since it is rich of antioxidant such as flavonoid and phenolic compounds and other mineral that women needed to prepare themselves to face pregnancy and maintain their reproduction system. Natural or herbal medicine is preferable due to minimum side effects even it consumed with high dose.

\section{REFERENCES}

1. Stephenson J. Europe PMC Funders Group Before the beginning: nutrition and lifestyle in the preconception period and its importance for future health. 2018;391(10132):1830-41.

2. Agarwal A, Aponte-Mellado A, Premkumar BJ, Shaman A, Gupta S. The effects of oxidative stress on female reproduction: A review. Reprod Biol Endocrinol [Internet]. 2012;10(1):1. Available from: Reproductive Biology and Endocrinology

3. Duhig K, Chappell LC, Shennan AH. Oxidative stress in pregnancy and reproduction. Obstet Med. 2016;9(3):113-6.

4. Mohammadi M. Oxidative Stress and Polycystic Ovary Syndrome: A Breif Review. Int J Prev Med. 2019;8:1-7.

5. Murad S, Niaz K, Aslam H. Effects of Ginger on LDL-C, Total Cholesterol and Body Weight. Clin Med Biochem. 2018;04(02):4-6.

6. Danwilai K, Konmun J, Sripanidkulchai BO, Subongkot S. Antioxidant activity of ginger extract 
as a daily supplement in cancer patients receiving adjuvant chemotherapy: A pilot study. Cancer Manag Res. 2017;9:11-8.

7. Chen CX, Barrett B, Kwekkeboom KL. Efficacy of Oral Ginger (Zingiber officinale) for Dysmenorrhea: A Systematic Review and MetaAnalysis. Evidence-based Complement Altern Med. 2016;2016.

8. Aschbacher K, Aoife 0, Wolkowitz 0, Dhabhar FS, Su Y, Epel E. Good Stress, Bad Stress and Oxidative Stress: Insights from Anticipatory Cortisol Reactivity Kirstin. 2013;38(9):1698-708.

9. Lee DY, Kim E, Choi MH. Technical and clinical aspects of cortisol as a biochemical marker of chronic stress. BMB Rep. 2015;48(4):20916.

10. Wiegner L, Hange D, Björkelund C, Ahlborg G. Prevalence of perceived stress and associations to symptoms of exhaustion, depression and anxiety in a working age population seeking primary care - An observational study. BMC Fam Pract. 2015;16(1):1-8.

11. Abdul Sani NF, Belani LK, Pui Sin C, Abdul Rahman SNA, Das S, Zar Chi T, et al. Effect of the combination of gelam honey and ginger on oxidative stress and metabolic profile in streptozotocin-induced diabetic sprague-dawley rats. Biomed Res Int. 2014;2014(Dm).

12. Eissa FA, Choudhry $\mathrm{H}$, Abdulaal WH, Baothman OA, Zeyadi M, Moselhy SS, et al. Possible Hypocholesterolemic Effect of Ginger and Rosemary Oils in Rats. African J Tradit Complement Altern Med AJTCAM. 2017;14(4):188-200.

13. Yllmaz N, Seven B, Timur H, Yorgancı A, İnal HA, Kalem MN, et al. Ginger (zingiber officinale) might improve female fertility: A rat model. J
Chinese Med Assoc. 2018;81(10):905-11.

14. Najim AJA-A. Potential health benefits and scientific review of ginger. J Pharmacogn Phyther. 2017;9(7):111-6.

15. Pasciu V, Baralla E, Varoni MV, Demontis MP. Evaluation of curcuma and ginger mixture ability to prevent ROS production induced by bisphenol S: an in vitro study. Drug Chem Toxicol [Internet]. 2019;0(0):1-7. Available from: https://doi.org/10.1080/01480545 .2019.1690499

16. Atashpour S, Jahromi HK, Jahromi ZK, Maleknasab M. Comparison of the effects of ginger extract with clomiphene citrate on sex hormones in rats with polycystic ovarian syndrome. Int J Reprod Biomed. 2017;15(9):561-8.

17. Permatasari AE, Nilawati A. The Effect of Ginger Honey and Cocktail Honey Supplementation on Cortisol Levels in Balb/c Female Mice Induced Stress. Int J Psychosoc Rehabil [Internet]. 2010;24(4):5533-40. Available from:

https://www.psychosocial.com/arti cle/PR201648/13858/

18. Ranabir S, Reetu K. Stress and hormones. Indian J Endocrinol Metab. 2011;15(1):18.

19. Khayat S, Kheirkhah M, Behboodi Moghadam Z, Fanaei H, Kasaeian A, Javadimehr M. Effect of Treatment with Ginger on the Severity of Premenstrual Syndrome Symptoms. ISRN Obstet Gynecol. 2014;2014:15. 